\title{
ANALISIS EVAPOTRANSPIRASI MENGGUNAKAN METODE PENMAN-MONTEITH PADA VERTICAL GARDEN
}

\author{
Arifin Daud $^{1)}$, Citra Indriyati ${ }^{2}{ }^{*}$, Sarah Yuli Hasanah ${ }^{3)}$ \\ ${ }^{1,2}$ Jurusan Teknik Sipil dan Perencanaan, FT UNSRI, Jl. Raya Palembang - Prabumulih Km. 32 Indralaya \\ ${ }^{3)}$ Program Sarjana Teknik Sipil, FT UNSRI, Jl. Raya Palembang - Prabumulih Km. 32 Indralaya
}

\begin{abstract}
The development of environmentally friendly infrastructure is very important to reduce the environmental damage that has occurred. Environmentally friendly infrastructure can be supported by vertical garden. Plants in vertical garden undergo evaporation process called evapotranspiration process. The evapotranspiration process can be used to find out the needs of water in plants. The method used to obtain the evapotranspiration value is the Penman-Monteith method. The plants used are Plectranthus scutellarioides, Begonia, Coleus, Euodia ridleyi dwarf, Euodia ridleyi, and Chlorophytum comosum. The reference evapotranspiration value in The Hydraulic Laboratory of Sriwijaya University is $4.9826 \mathrm{~mm} /$ day and the smallest is $2.1262 \mathrm{~mm} /$ day. The reference evapotranspiration value is influenced by temperature, wind speed, and humidity conditions. Based on these three influences, temperature has a greater influence on the reference evapotranspiration. The largest evapotranspiration value of the six types of plants used is the Plectranthus scutellarioides, which is $3.3347 \mathrm{~mm} /$ day, the evapotranspiration value of the smallest plant is Euodia ridleyi dwarf, which is $2.6616 \mathrm{~mm} /$ day. The location and arrangement of plants and environmental conditions such as temperature, humidity, wind speed affect the amount of evapotranspiration value.
\end{abstract}

Key Words: evapotranspiration, Penman-Monteith, vertical garden

\section{PENDAHULUAN}

Kerusakan lingkungan dapat diminimalisir dengan pembangunan infrastruktur yang ramah lingkungan, salah satunya infrastruktur yang didukung oleh tersedianya vertical garden. Vertical garden berfungsi sebagai penahan panas, mengurangi polusi (udara), dan meningkatkan suplai oksigen. Fasad hijau dapat menurunkan suhu dalam ruangan hingga $3,60{ }^{\circ} \mathrm{C}$ dan suhu luar ruangan hingga $2,70{ }^{\circ} \mathrm{C}$ (Zhang dkk., 2019).

Umumnya, vertical garden menggunakan tanaman lokal yang mudah ditemui dan/atau dirawat. Terdapat dua sistem vertical garden, yaitu: green facades dan modular vertical garden. Pada sistem green facades, digunakan tanaman yang merambat pada dinding. Sedangkan pada modular vertical garden, digunakan tanaman yang dilengkapi wadah, (Virtudes dan Manso, 2016). Pot/kantong tanaman dapat digunakan untuk modular vertical garden dan disusun secara bertingkat. Agar tanaman tumbuh, dibutuhkan suplai air yang tidak berlebih dan/atau tidak kekurangan.

Kebutuhan air tanaman tergantung pada proses yang terjadi pada tanaman, misalnya proses penguapan atau evapotranspirasi. Baruga, dkk. (2019) menyatakan bahwa evapotranspirasi merupakan penguapan pada permukaan lahan yang terdapat tanah dan tanaman di permukaan lahan tersebut.

Evapotranspirasi merupakan salah satu parameter acuan dalam memperkirakan kebutuhan air tanaman (Wouw dkk., 2017). Estimasi kebutuhan air tanaman dilakukan untuk membantu upaya penghematan konsumsi air. Sehingga, penelitian terkait besarnya evapotranspirasi pada tanaman di vertical garden ini dilakukan. Penelitian ini menggunakan metode Penman-Monteith (Allen dkk., 1998) untuk mendapatkan nilai evapotranspirasi acuan. Penelitian ini menggunakan modular vertical garden dan dilakukan di dalam ruangan (Cardozo dkk., 2019).

\section{METODOLOGI}

Penelitian ini merupakan penelitian eksperimental laboratorium menggunakan metode Penman-Monteith. Allen dkk (1998) menyatakan bahwa metode Penman-Monteith merupakan metode terbaik dalam mengestimasi evapotranspirasi tanaman acuan. Besar estimasi kesalahan standar pada metode Penman-Monteith menunjukkan nilai terkecil, yaitu sebesar 0,32 sedangkan metode lainnya antara 0,56 sampai 1,29 (Allen dkk, 1998).

Vertical garden yang digunakan pada penelitian adalah modular vertical garden, dengan pot 
tanaman sebagai wadah media tanam. Data evapotranspirasi diambil untuk setiap tanaman dengan susunan satu jenis tanaman pada arah horizontal (Gambar 1). Vertical garden dibuat di Laboratorium Hidraulika UNSRI (Gambar 2).

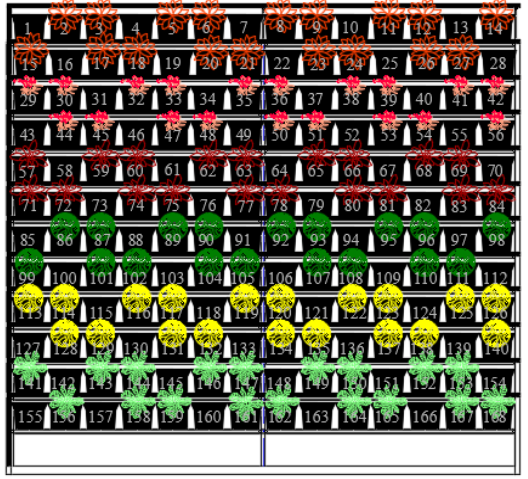

Gambar 1. Susunan tanaman vertical garden

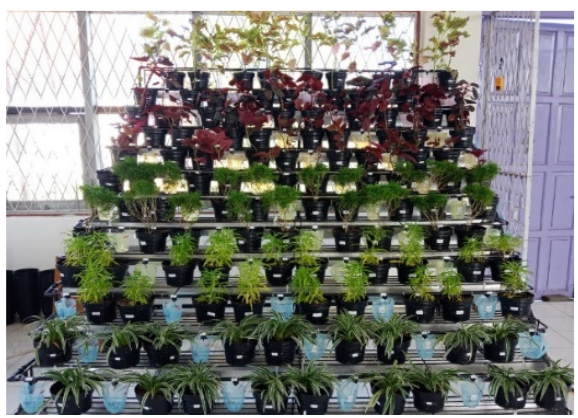

Gambar 2. Vertical garden

Tahap selanjutnya adalah persiapan alat dan tanaman, berupa: digital wind anemometer yang dapat mengukur kecepatan $0-30 \mathrm{~m} / \mathrm{s}$, termometer, gelas ukur $500 \mathrm{ml}$, timbangan digital dengan ketelitian $1 \times 10^{-3} \mathrm{gr}$, pot tanaman berbahan plastik dengan diameter $16 \mathrm{~cm}$, tinggi $12 \mathrm{~cm}$, dan media tanam berupa tanah humus. Tanaman yang digunakan merupakan tanaman lokal, yang mudah ditemui di Kota Palembang (Gambar 3).

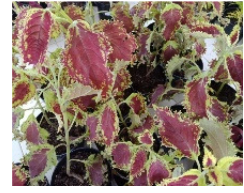

(a)

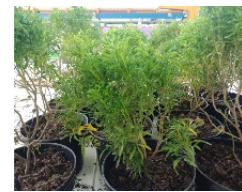

(d)

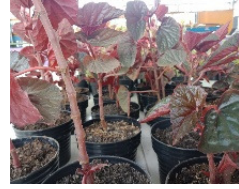

(b)

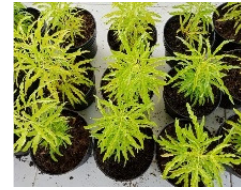

(e)

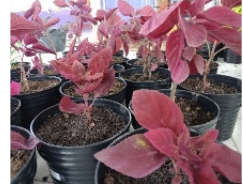

(c)

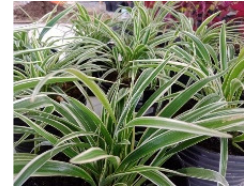

(f)
Gambar 3. (a) Plectranthus scutellarioides, (b) Begonia, (c) Coleus, (d) Euodia ridleyi dwarf, (e) Euodia ridleyi, (f) Chlorophytum comosum
Selanjutnya adalah pengambilan data evapotranspirasi, dalam pada rentang masa uji 01 September 2020 s.d 30 September 2020. Data yang diambil sebagai berikut:

\section{Volume air Suplai}

Suplai air diukur pada penampung air di pot tanaman. Data diukur setelah penyiraman tanaman, dan tidak ada tetesan air (Gambar 4). Penyiraman dilakukan pukul 08.00 WIB.

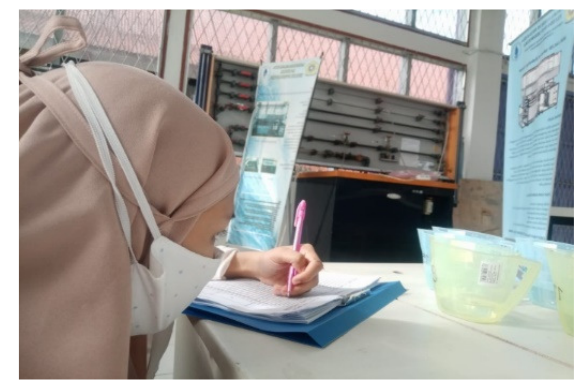

Gambar 4. Pengambilan data volume air yang diberikan

2. Volume air terbuang

Volume air terbuang diukur pada penampung air yang keluar dari lubang pot tanaman. Pengukuran dilakukan untuk tiap jenis tanaman pada pukul 13.00 WIB, setelah semua air terserap, dan sisanya keluar melalui lubang pot.

3. Luas permukaan tanah

Luas permukaan tanah di dalam pot diperoleh melalui perhitungan luas lingkaran, karena permukaan tanah pada pot berbentuk lingkaran.

4. Suhu, kelembapan, dan kecepatan angin

Data suhu dan kelembapan didapatkan melalui hasil pengukuran dari termometer. Data kecepatan angin didapatkan melalui hasil pengukuran dari digital wind anemometer. Pengambilan data dilakukan pada pukul 07.00 WIB, 13.00 WIB, dan 18.00 WIB. Penentuan pengambilan data tersebut mengacu pada aturan BMKG.

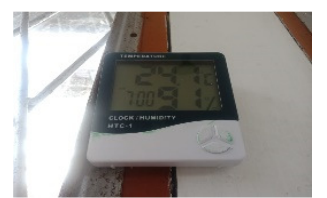

(a)

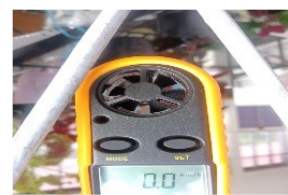

(b)
Gambar 5. Pengukuran suhu, kelembapan, dan kecepatan angin

\section{Topografi}

Data topografi berupa elevasi laboratorium Hidraulika, yaitu 6,229 $\mathrm{m}$ di atas muka laut, dan terletak di $3,14^{0}$ LS dan $104,38^{0}$ LE (Putranto dkk., 2020). 
Cantilever $\mid$ Volume: 10 Nomor: 01 April $2021 \mid$ ISSN: 1907-4247 (Print) $\mid$ ISSN: 2477-4863 (Online) $\mid$ Website: http://cantilever.id Arifin Daud, dkk. | Analisis Evapotranspirasi Menggunakan Metode Penman-Monteith pada Vertical Garden

6. Kadar air tanah

Kadar air (tanah) diukur dengan menimbang berat cawan kosong, berat cawan + tanah basah, dan berat cawan + tanah kering (pada oven 110 ${ }^{0} \mathrm{C}$ ). Pengambilan data dilakukan sebelum dan setelah tanah disiram.

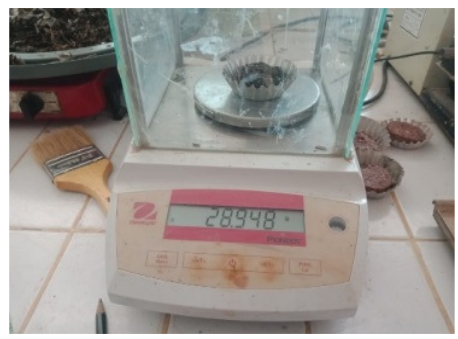

Gambar 6. Pengambilan data kadar air tanah

\section{HASIL DAN PEMBAHASAN}

\section{1) Evapotranspirasi acuan $\left(E T_{0}\right)$}

Evapotranspirasi acuan berdasarkan SNI 7745:2012, dengan metode Penman-Monteith. Hasil perhitungan evapotranspirasi acuan pada 01 September 2020, berdasarkan suhu, kelembapan, dan kecepatan angin, di Laboratorium Hidraulika UNSRI, sebagai berikut:

$E T_{0}=\frac{0,408(0,22)(13,27)+0,068 \frac{900}{(28,27+273)} 0,77(1,25)}{(0,2231+0,0678(1+0,34(0,7685)))}$

$E T_{0}=4,55 \mathrm{~mm} /$ hari

Evapotranspirasi acuan pada Laboratorium Hidraulika UNSRI, tanggal 01 September 2020 yaitu 4,55 mm/hari. Tabel 1 menyajikan rekapitulasi hasil evapotranspirasi acuan.

Tabel 1. Rekapitulasi hasil evapotranspirasi acuan

\begin{tabular}{lllll}
\hline Tanggal & $\mathrm{T}\left({ }^{\circ} \mathrm{C}\right)$ & $\mathrm{RH}(\%)$ & $\mathrm{U}_{2}(\mathrm{~m} / \mathrm{s})$ & $\mathrm{ET}_{0}(\mathrm{~mm} /$ hari $)$ \\
\hline 1 September 2020 & 28,27 & 67,33 & 0,77 & 4,5475 \\
2 September 2020 & 27,43 & 69,67 & 0,24 & 3,2124 \\
3 September 2020 & 24,70 & 92,00 & 0,45 & 3,0101 \\
4 September 2020 & 26,87 & 78,67 & 0,51 & 2,2182 \\
8 September 2020 & 27,90 & 70,67 & 0,64 & 4,0041 \\
9 September 2020 & 26,93 & 78,67 & 0,76 & 3,8035 \\
10 September 2020 & 25,77 & 85,67 & 0,34 & 3,0475 \\
11 September 2020 & 27,90 & 69,00 & 0,55 & 3,2388 \\
15 September 2020 & 28,17 & 69,00 & 0,01 & 2,3884 \\
16 September 2020 & 27,37 & 72,33 & 0,01 & 3,5352 \\
17 September 2020 & 28,50 & 61,00 & 0,26 & 3,9702 \\
18 September 2020 & 27,77 & 67,67 & 0,95 & 3,5693 \\
22 September 2020 & 28,00 & 71,67 & 0,03 & 2,1262 \\
23 September 2020 & 29,30 & 67,67 & 0,44 & 4,3480 \\
24 September 2020 & 29,27 & 64,67 & 0,01 & 4,2324 \\
25 September 2020 & 28,10 & 77,33 & 0,26 & 4,8374 \\
29 September 2020 & 28,37 & 67,67 & 0,44 & 4,8319 \\
30 September 2020 & 27,70 & 73,33 & 0,58 & 4,9826
\end{tabular}

Nilai evapotranspirasi acuan maksimum $(=4,98$ $\mathrm{mm} /$ hari), sedangkan nilai evapotranspirasi acuan minimum (=2,13 $\mathrm{mm} /$ hari), lihat Tabel 1. Tabel 1 memperlihatkan pengaruh suhu, kelembapan, dan kecepatan angin terhadap evapotranspirasi acuan (Gambar 7 s.d Gambar 9).

Berdasarkan Gambar 7, diperoleh koefisien korelasi suhu dan evapotranspirasi acuan sebesar 0,43. Koefisien korelasi kelembapan dan evapotranspirasi acuan sebesar -0,31 (Gambar 8). Sedangkan koefisien korelasi kecepatan angin dengan evapotranspirasi acuan sebesar 0,29 (Gambar 9).

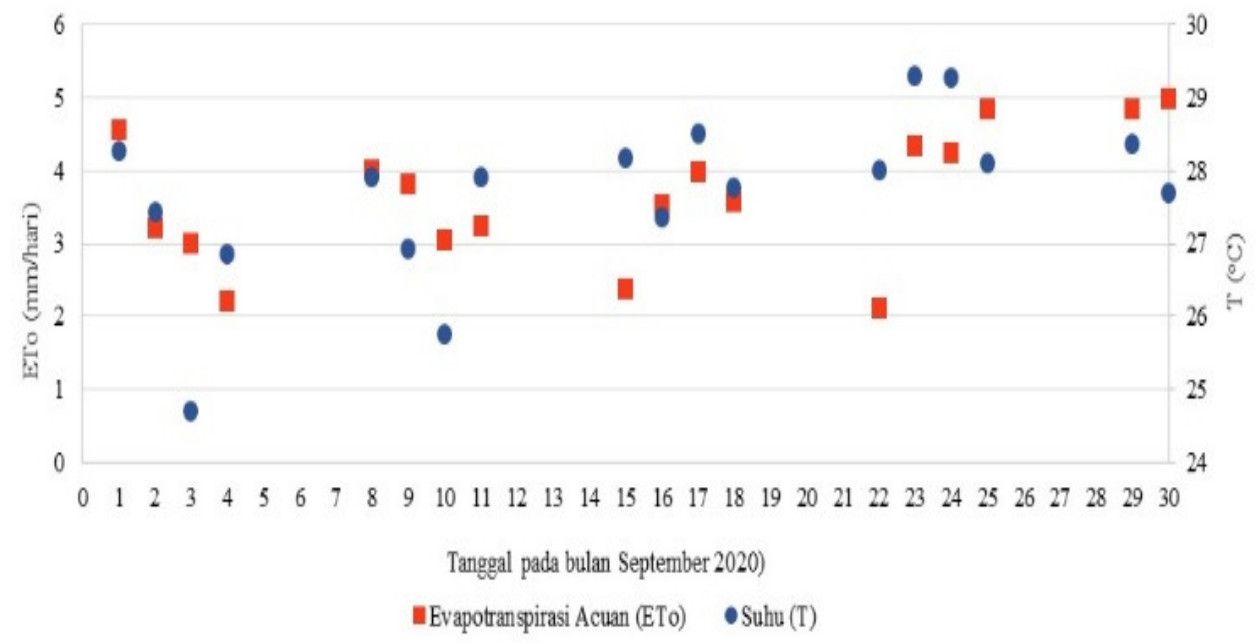

Gambar 7. Grafik hubungan nilai $T$ terhadap $E T_{0}$ 


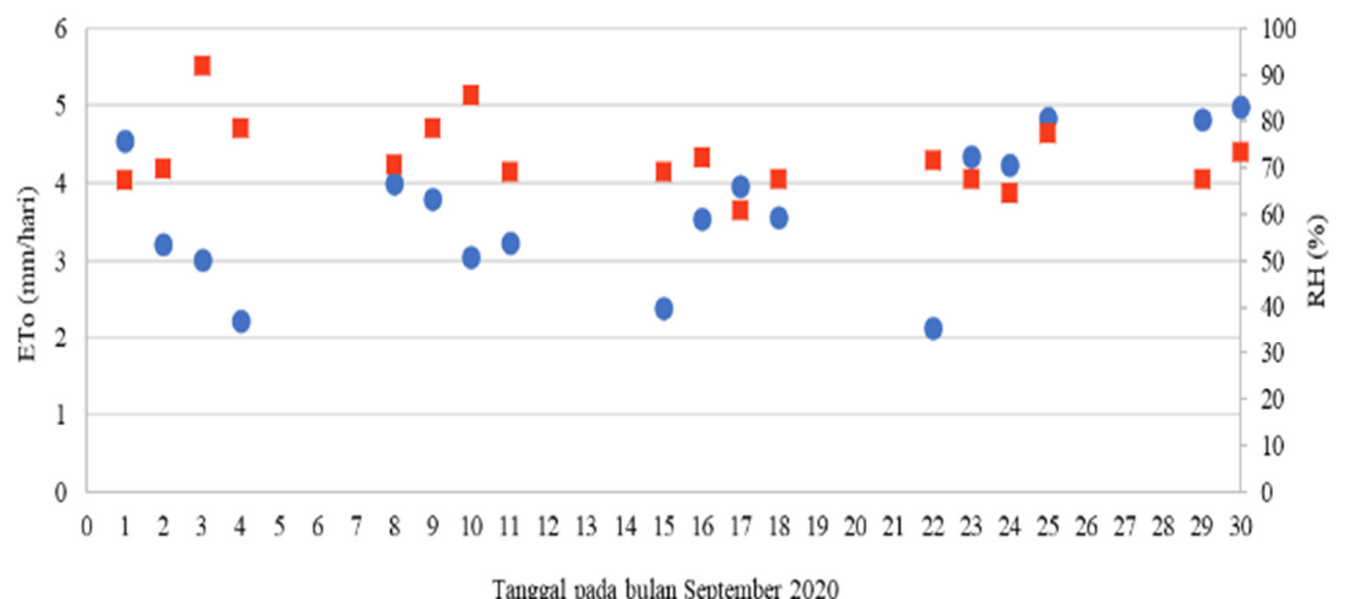

-Evapotranspirasi Acuan (ETo) $\quad$ Kelembapan (RH)

Gambar 8. Grafik hubungan nilai $R H$ terhadap $E T_{0}$

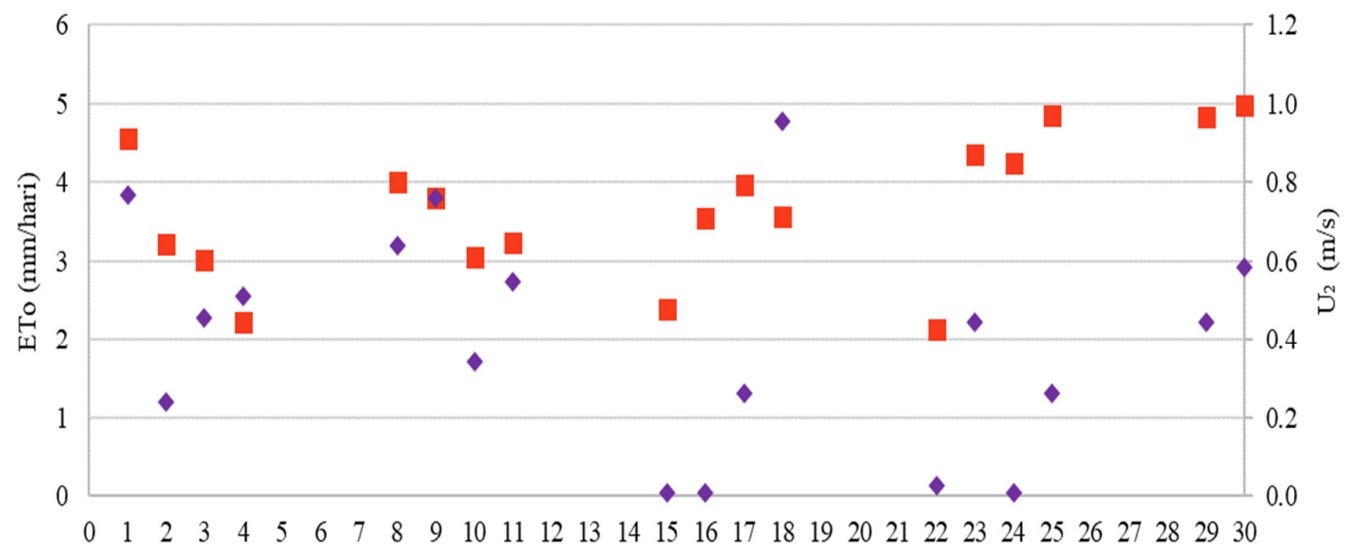

Tanggal pada bulan September 2020

Evapotranspirasi Acuan (ETo) $\diamond$ Kecepatan Angin (U2)

Gambar 9. Grafik hubungan nilai $U_{2}$ terhadap $E T_{0}$

\section{2) Evapotranspirasi tanaman $\left(E T_{c}\right)$}

Evapotranspirasi tanaman dihitung berdasarkan selisih volume air yang diberikan $\left(V_{0}\right)$ dan volume air terbuang $\left(V_{l}\right)$, dan selisih kadar air tanah $(\Delta$ $K A T$ ) dibagi dengan luas permukaan tanah. Untuk mendapatkan hasil evapotranspirasi tanaman, maka dilakukan perhitungan persentase kadar air tanah terlebih dahulu. Berikut perhitungan kadar air tanah asli pada Sampel 1:

$K A T=\frac{25,233-16,841}{16,841-3,541} \times 100 \%=63,10 \%$

Sehingga, diperoleh kadar air tanah asli Sampel 1 adalah 63,10\%. Rekapitulasi kadar air tanah ditampilkan pada Tabel 2. Dari Tabel 2, kadar air tanah asli rata-rata adalah $65,27 \%$. Kadar air tanah terbesar setelah penyiraman pada Chlorophytum Comosum $(=73,74 \%)$. Sedangkan kadar air tanah (setelah penyiraman) terendah pada Plectranthus Scutellarioides, $(=66,17 \%)$.

Tabel 2. Rekapitulasi kadar air tanah

\begin{tabular}{lcc}
\hline \multicolumn{1}{c}{ Kadar air tanah } & Rata-rata (\%) & $\Delta$ KAT (\%) \\
\hline Asli & 65,273 & - \\
Tanaman Plectranthus scutellarioides & 66,170 & 0,897 \\
Tanaman Begonia & 68,693 & 3,420 \\
Tanaman Coleus & 69,223 & 3,950 \\
Tanaman Euodia ridleyi dwarf & 69,979 & 4,706 \\
Tanaman Euodia ridleyi & 71,054 & 5,781 \\
Tanaman Chlorophytum comosum & 73,740 & 8,468
\end{tabular}

Berikutnya, dihitung luas permukaan tanah (A) pada setiap pot tanaman, dengan jari-jari lingkaran sebesar $8 \mathrm{~cm}$, yaitu:

$$
A=\pi 8^{2}=201,06 \mathrm{~cm}^{2}
$$




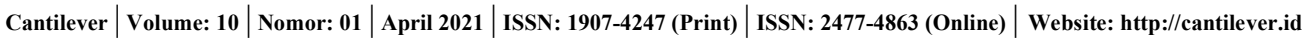
Arifin Daud, dkk. | Analisis Evapotranspirasi Menggunakan Metode Penman-Monteith pada Vertical Garden

Selanjutnya adalah mengubah kadar air tanah yang pada awalnya dalam persen menjadi ml. Kadar air tanah (dalam satuan $\mathrm{ml}$ ) pada 01 September 2020, dihitung dengan:

$$
\begin{aligned}
\Delta K A T & =\frac{\Delta K A T \% \times(\mathrm{V} 0-\mathrm{V} 1)}{100} \\
\Delta K A T & =\frac{0,90 \% \times(72,68-1,39)}{100}=0,64 \mathrm{ml}
\end{aligned}
$$

Evapotranspirasi tanaman dihitung berdasarkan: (a) pengurangan air yang diberikan dan (b) air yang terbuang, serta air yang terdapat pada tanah. Sebagai contoh, evapotranspirasi Plectranthus Scutellarioides pada 01 September 2020, adalah:

$$
E T_{c}=\frac{(72,68-1,39-0,64) \mathrm{ml}}{201,06 \mathrm{~cm}^{2}} \times 10=3,51 \mathrm{~mm} / \mathrm{hari}
$$

Selanjutnya dengan menggunakan persamaan dan cara yang sama, didapatkan nilai evapotranspirasi acuan untuk semua jenis tanaman yang digunakan, dapat dilihat pada Tabel 3 s.d Tabel 8 .

Tabel 3. Nilai $\mathrm{ET}_{\mathrm{c}}$ Plectranthus scutellarioides

\begin{tabular}{llllll}
\hline Tanggal & $\mathrm{V}_{0}(\mathrm{ml})$ & $\mathrm{V}_{1}(\mathrm{ml})$ & $\Delta \mathrm{KAT}$ & $\mathrm{A}\left(\mathrm{cm}^{2}\right)$ & $\mathrm{ETc}(\mathrm{mm} / \mathrm{hari})$ \\
\hline 1 September 2020 & 72,68 & 1,39 & 0,64 & 201,0619 & 3,5139 \\
2 September 2020 & 72,08 & 1,67 & 0,61 & 201,0619 & 3,3613 \\
3 September 2020 & 80,24 & 3,06 & 0,69 & 201,0619 & 3,8043 \\
4 September 2020 & 79,17 & 13,33 & 0,59 & 201,0619 & 3,2449 \\
8 September 2020 & 77,98 & 5,00 & 0,65 & 201,0619 & 3,5970 \\
9 September 2020 & 86,73 & 4,06 & 0,74 & 201,0619 & 4,0748 \\
10 September 2020 & 82,74 & 2,78 & 0,72 & 201,0619 & 3,9412 \\
11 September 2020 & 88,10 & 5,28 & 0,74 & 201,0619 & 4,0821 \\
15 September 2020 & 80,48 & 5,00 & 0,68 & 201,0619 & 3,7202 \\
16 September 2020 & 84,17 & 29,17 & 0,49 & 201,0619 & 2,7109 \\
17 September 2020 & 77,02 & 26,94 & 0,45 & 201,0619 & 2,4684 \\
18 September 2020 & 77,02 & 28,33 & 0,44 & 201,0619 & 2,3999 \\
22 September 2020 & 78,93 & 21,67 & 0,51 & 201,0619 & 2,8224 \\
23 September 2020 & 74,94 & 6,67 & 0,61 & 201,0619 & 3,3652 \\
24 September 2020 & 72,56 & 7,50 & 0,58 & 201,0619 & 3,2068 \\
25 September 2020 & 85,00 & 12,78 & 0,65 & 201,0619 & 3,5598 \\
29 September 2020 & 81,49 & 15,83 & 0,59 & 201,0619 & 3,2361 \\
30 September 2020 & 78,04 & 18,89 & 0,53 & 201,0619 & 2,9153 \\
\hline Rata-rata & 79,41 & 11,75 & 0,61 & 201,0619 & 3,3347 \\
\hline
\end{tabular}

Tabel 3 memperlihatkan evapotranspirasi Plectranthus Scutellarioides terbesar adalah 4,08 $\mathrm{mm} /$ hari, dan terkecil adalah $2,40 \mathrm{~mm} /$ hari, dengan rata-rata sebesar $3,33 \mathrm{~mm} /$ hari. Evapotranspirasi Begonia terbesar adalah $3,04 \mathrm{~mm} /$ hari, terkecil adalah 1,35 $\mathrm{mm} /$ hari, dan rata-rata sebesar 2,49 $\mathrm{mm} /$ hari (Tabel 4). Sedangkan evapotranspirasi Coleus terbesar adalah $2,9531 \mathrm{~mm} /$ hari, terkecil adalah 1,21 $\mathrm{mm} /$ hari, dengan rata-rata sebesar 2,32 $\mathrm{mm} /$ hari (Tabel 5).
Tabel 4. Nilai $\mathrm{ET}_{\mathrm{c}}$ Begonia

\begin{tabular}{llllll}
\hline Tanggal & $\mathrm{V}_{0}(\mathrm{ml})$ & $\mathrm{V}_{1}(\mathrm{ml})$ & $\Delta \mathrm{KAT}$ & $\mathrm{A}\left(\mathrm{cm}^{2}\right)$ & ETc (mm/hari) \\
\hline 1 September 2020 & 86,37 & 26,67 & 2,04 & 201,0619 & 2,8678 \\
2 September 2020 & 88,51 & 27,81 & 2,08 & 201,0619 & 2,9160 \\
3 September 2020 & 93,21 & 50,03 & 1,48 & 201,0619 & 2,0745 \\
4 September 2020 & 93,21 & 65,17 & 0,96 & 201,0619 & 1,3473 \\
8 September 2020 & 98,21 & 45,03 & 1,82 & 201,0619 & 2,5548 \\
9 September 2020 & 100,30 & 48,61 & 1,77 & 201,0619 & 2,4827 \\
10 September 2020 & 97,02 & 54,86 & 1,44 & 201,0619 & 2,0253 \\
11 September 2020 & 99,17 & 56,17 & 1,47 & 201,0619 & 2,0655 \\
15 September 2020 & 94,40 & 45,56 & 1,67 & 201,0619 & 2,3465 \\
16 September 2020 & 95,24 & 42,22 & 1,81 & 201,0619 & 2,5466 \\
17 September 2020 & 95,24 & 41,39 & 1,84 & 201,0619 & 2,5866 \\
18 September 2020 & 95,48 & 39,39 & 1,92 & 201,0619 & 2,6941 \\
22 September 2020 & 91,07 & 51,56 & 1,35 & 201,0619 & 1,8981 \\
23 September 2020 & 91,61 & 36,33 & 1,89 & 201,0619 & 2,6551 \\
& & & & & \\
24 September 2020 & 90,65 & 30,00 & 2,07 & 201,0619 & 2,9135 \\
25 September 2020 & 100,36 & 40,14 & 2,06 & 201,0619 & 2,8926 \\
29 September 2020 & 100,30 & 37,00 & 2,17 & 201,0619 & 3,0405 \\
30 September 2020 & 96,13 & 37,28 & 2,01 & 201,0619 & 2,8270 \\
\hline Rata-rata & 94,80 & 43,07 & 1,77 & 201,0619 & 2,4852 \\
\hline
\end{tabular}

Tabel 5. Nilai $\mathrm{ET}_{\mathrm{c}}$ Coleus

\begin{tabular}{llllll}
\hline Tanggal & $\mathrm{V}_{0}(\mathrm{ml})$ & $\mathrm{V}_{1}(\mathrm{ml})$ & $\Delta \mathrm{KAT}$ & $\mathrm{A}\left(\mathrm{cm}^{2}\right)$ & $\mathrm{ETc}(\mathrm{mm} / \mathrm{har})$ \\
\hline 1 September 2020 & 91,31 & 34,17 & 2,26 & 201,0619 & 2,7298 \\
2 September 2020 & 95,18 & 33,36 & 2,44 & 201,0619 & 2,9531 \\
3 September 2020 & 97,38 & 47,72 & 1,96 & 201,0619 & 2,3723 \\
4 September 2020 & 97,32 & 71,94 & 1,00 & 201,0619 & 1,2123 \\
8 September 2020 & 105,48 & 53,25 & 2,06 & 201,0619 & 2,4949 \\
9 September 2020 & 105,18 & 55,00 & 1,98 & 201,0619 & 2,3971 \\
10 September 2020 & 101,61 & 61,14 & 1,60 & 201,0619 & 1,9332 \\
11 September 2020 & 100,95 & 65,94 & 1,38 & 201,0619 & 1,6724 \\
15 September 2020 & 101,43 & 59,08 & 1,67 & 201,0619 & 2,0229 \\
16 September 2020 & 100,00 & 54,50 & 1,80 & 201,0619 & 2,1736 \\
17 September 2020 & 104,46 & 53,36 & 2,02 & 201,0619 & 2,4413 \\
18 September 2020 & 103,81 & 50,42 & 2,11 & 201,0619 & 2,5507 \\
22 September 2020 & 97,02 & 65,83 & 1,23 & 201,0619 & 1,4900 \\
23 September 2020 & 100,48 & 50,97 & 1,96 & 201,0619 & 2,3649 \\
24 September 2020 & 101,07 & 43,06 & 2,29 & 201,0619 & 2,7715 \\
25 September 2020 & 107,74 & 49,39 & 2,30 & 201,0619 & 2,7874 \\
29 September 2020 & 107,50 & 50,19 & 2,26 & 201,0619 & 2,7376 \\
30 September 2020 & 103,69 & 47,92 & 2,20 & 201,0619 & 2,6644 \\
\hline Rata-rata & 101,20 & 52,63 & 1,92 & 201,0619 & 2,3205 \\
\hline
\end{tabular}

Tabel 6. Nilai $\mathrm{ET}_{\mathrm{c}}$ Euodia ridleyi dwarf

\begin{tabular}{llllll}
\hline Tanggal & $\mathrm{V}_{0}(\mathrm{ml})$ & $\mathrm{V}_{1}(\mathrm{ml})$ & $\Delta \mathrm{KAT}$ & $\mathrm{A}\left(\mathrm{cm}^{2}\right)$ & $\mathrm{ETc}(\mathrm{mm} / \mathrm{hari})$ \\
\hline 1 September 2020 & 96,43 & 42,50 & 2,54 & 201,0619 & 2,5560 \\
2 September 2020 & 99,52 & 41,94 & 2,71 & 201,0619 & 2,7290 \\
3 September 2020 & 101,67 & 65,00 & 1,73 & 201,0619 & 1,7378 \\
4 September 2020 & 100,89 & 70,56 & 1,43 & 201,0619 & 1,4378 \\
8 September 2020 & 106,43 & 61,11 & 2,13 & 201,0619 & 2,1478 \\
9 September 2020 & 109,76 & 59,72 & 2,36 & 201,0619 & 2,3716 \\
10 September 2020 & 106,07 & 68,61 & 1,76 & 201,0619 & 1,7754 \\
11 September 2020 & 106,07 & 71,67 & 1,62 & 201,0619 & 1,6306 \\
15 September 2020 & 110,00 & 66,11 & 2,07 & 201,0619 & 2,0801 \\
16 September 2020 & 105,42 & 65,56 & 1,88 & 201,0619 & 1,8892 \\
17 September 2020 & 108,21 & 67,78 & 1,90 & 201,0619 & 1,9165 \\
18 September 2020 & 107,20 & 63,06 & 2,08 & 201,0619 & 2,0923 \\
22 September 2020 & 105,54 & 76,67 & 1,36 & 201,0619 & 1,3683 \\
23 September 2020 & 107,56 & 63,89 & 2,06 & 201,0619 & 2,0698 \\
24 September 2020 & 106,79 & 59,17 & 2,24 & 201,0619 & 2,2569 \\
25 September 2020 & 111,43 & 64,17 & 2,22 & 201,0619 & 2,2400 \\
29 September 2020 & 109,64 & 63,33 & 2,18 & 201,0619 & 2,1948 \\
30 September 2020 & 107,86 & 61,67 & 2,17 & 201,0619 & 2,1892 \\
\hline Rata-rata & 105,92 & 62,92 & 2,02 & 201,0619 & 2,0380 \\
\hline
\end{tabular}


Evapotranspirasi Euodia Ridleyi Dwarf terbesar adalah 2,73 $\mathrm{mm} / \mathrm{hari}$, dan terkecil adalah 1,37 $\mathrm{mm} /$ hari, sedangkan rata-rata evapotranspirasi adalah 2,04 mm/hari (Tabel 6).

Tabel 7. Nilai $\mathrm{ET}_{\mathrm{c}}$ Euodia ridleyi

\begin{tabular}{llllll}
\hline Tanggal & $\mathrm{V}_{0}(\mathrm{ml})$ & $\mathrm{V}_{1}(\mathrm{ml})$ & $\Delta \mathrm{KAT}$ & $\mathrm{A}\left(\mathrm{cm}^{2}\right)$ & ETc $(\mathrm{mm} / \mathrm{hari})$ \\
\hline 1 September 2020 & 121,31 & 53,83 & 3,90 & 201,0619 & 3,1620 \\
2 September 2020 & 124,46 & 54,64 & 4,04 & 201,0619 & 3,2721 \\
3 September 2020 & 123,81 & 76,39 & 2,74 & 201,0619 & 2,2222 \\
4 September 2020 & 124,17 & 92,50 & 1,83 & 201,0619 & 1,4839 \\
8 September 2020 & 126,55 & 76,36 & 2,90 & 201,0619 & 2,3518 \\
9 September 2020 & 130,24 & 80,42 & 2,88 & 201,0619 & 2,3347 \\
10 September 2020 & 126,55 & 86,44 & 2,32 & 201,0619 & 1,8793 \\
11 September 2020 & 127,50 & 85,50 & 2,43 & 201,0619 & 1,9681 \\
15 September 2020 & 129,35 & 82,56 & 2,70 & 201,0619 & 2,1926 \\
16 September 2020 & 125,36 & 80,53 & 2,59 & 201,0619 & 2,1007 \\
17 September 2020 & 125,48 & 82,28 & 2,50 & 201,0619 & 2,0243 \\
18 September 2020 & 129,11 & 77,36 & 2,99 & 201,0619 & 2,4249 \\
22 September 2020 & 129,88 & 87,08 & 2,47 & 201,0619 & 2,0055 \\
23 September 2020 & 131,19 & 72,00 & 3,42 & 201,0619 & 2,7737 \\
24 September 2020 & 128,87 & 68,89 & 3,47 & 201,0619 & 2,8107 \\
25 September 2020 & 134,29 & 72,78 & 3,56 & 201,0619 & 2,8823 \\
29 September 2020 & 133,57 & 73,14 & 3,49 & 201,0619 & 2,8319 \\
30 September 2020 & 133,39 & 70,78 & 3,62 & 201,0619 & 2,9342 \\
\hline Rata-rata & 128,06 & 76,30 & 2,99 & 201,0619 & 2,4253 \\
\hline
\end{tabular}

Berdasarkan Tabel 7, evapotranspirasi Euodia Ridleyi terbesar adalah $3,27 \mathrm{~mm} / \mathrm{hari}$, dan terkecil adalah $1,48 \mathrm{~mm} /$ hari, dengan rata-rata sebesar 2,42 $\mathrm{mm} / \mathrm{hari}$.

Tabel 8. Nilai $\mathrm{ET}_{\mathrm{c}}$ Chlorophytum comosum

\begin{tabular}{llllll}
\hline Tanggal & $\mathrm{V}_{0}(\mathrm{ml})$ & $\mathrm{V}_{1}(\mathrm{ml})$ & $\Delta \mathrm{KAT}$ & $\mathrm{A}\left(\mathrm{cm}^{2}\right)$ & ETc (mm/hari) \\
\hline 1 September 2020 & 149,82 & 77,22 & 6,15 & 201,0619 & 3,3050 \\
2 September 2020 & 152,14 & 76,94 & 6,37 & 201,0619 & 3,4234 \\
3 September 2020 & 149,82 & 87,22 & 5,30 & 201,0619 & 2,8498 \\
4 September 2020 & 150,06 & 102,22 & 4,05 & 201,0619 & 2,1778 \\
8 September 2020 & 153,21 & 101,11 & 4,41 & 201,0619 & 2,3720 \\
9 September 2020 & 155,77 & 99,17 & 4,79 & 201,0619 & 2,5770 \\
10 September 2020 & 152,35 & 106,67 & 3,87 & 201,0619 & 2,0798 \\
11 September 2020 & 153,10 & 103,61 & 4,19 & 201,0619 & 2,2527 \\
15 September 2020 & 148,93 & 102,50 & 3,93 & 201,0619 & 2,1136 \\
16 September 2020 & 151,58 & 100,28 & 4,34 & 201,0619 & 2,3354 \\
17 September 2020 & 149,32 & 101,94 & 4,01 & 201,0619 & 2,1565 \\
18 September 2020 & 155,33 & 99,17 & 4,76 & 201,0619 & 2,5567 \\
22 September 2020 & 159,82 & 108,33 & 4,36 & 201,0619 & 2,3440 \\
23 September 2020 & 158,13 & 96,67 & 5,20 & 201,0619 & 2,7979 \\
24 September 2020 & 154,46 & 92,22 & 5,27 & 201,0619 & 2,8335 \\
25 September 2020 & 162,50 & 90,00 & 6,14 & 201,0619 & 3,3005 \\
29 September 2020 & 162,89 & 91,67 & 6,03 & 201,0619 & 3,2423 \\
30 September 2020 & 161,19 & 91,11 & 5,93 & 201,0619 & 3,1903 \\
\hline Rata-rata & 154,47 & 96,00 & 4,95 & 201,0619 & 2,6616 \\
\hline
\end{tabular}

Evapotranspirasi Chlorophytum Comosum terbesar adalah $3,42 \mathrm{~mm} /$ hari, dan terkecil adalah $2,08 \mathrm{~mm} /$ hari, dengan rata-rata sebesar 2,66 $\mathrm{mm} /$ hari (Tabel 8). Rekapitulasi evapotranspirasi tanaman dari enam jenis tanaman yang digunakan pada penelitian dapat dilihat pada Tabel 9 .
Tabel 9. Rekapitulasi nilai evapotranspirasi tanaman

\begin{tabular}{|c|c|c|c|c|c|c|}
\hline \multirow[b]{2}{*}{ Tanggal } & \multicolumn{6}{|c|}{ ETc (mm/hari) } \\
\hline & $\begin{array}{c}\text { Plectranthus } \\
\text { scutellarioides }\end{array}$ & Begonia & Coleus & $\begin{array}{l}\text { Euodia } \\
\text { ridleyi } \\
\text { dwarf }\end{array}$ & $\begin{array}{l}\text { Euodia } \\
\text { ridleyi }\end{array}$ & $\begin{array}{l}\text { Chlorophy } \\
\text { tum } \\
\text { comosum }\end{array}$ \\
\hline 1 September 2020 & 3,5139 & 2,8678 & 2,7298 & 2,5560 & 3,1620 & 3,3050 \\
\hline 2 September 2020 & 3,3613 & 2,9160 & 2,9531 & 2,7290 & 3,2721 & 3,4234 \\
\hline 3 September 2020 & 3,8043 & 2,0745 & 2,3723 & 1,7378 & 2,2222 & 2,8498 \\
\hline 4 September 2020 & 3,2449 & 1,3473 & 1,2123 & 1,4378 & 1,4839 & 2,1778 \\
\hline 8 September 2020 & 3,5970 & 2,5548 & 2,4949 & 2,1478 & 2,3518 & 2,3720 \\
\hline 9 September 2020 & 4,0748 & 2,4827 & 2,3971 & 2,3716 & 2,3347 & 2,5770 \\
\hline 10 September 2020 & 3,9412 & 2,0253 & 1,9332 & 1,7754 & 1,8793 & 2,0798 \\
\hline 11 September 2020 & 4,0821 & 2,0655 & 1,6724 & 1,6306 & 1,9681 & 2,2527 \\
\hline 15 September 2020 & 3,7202 & 2,3465 & 2,0229 & 2,0801 & 2,1926 & 2,1136 \\
\hline 16 September 2020 & 2,7109 & 2,5466 & 2,1736 & 1,8892 & 2,1007 & 2,3354 \\
\hline 17 September 2020 & 2,4684 & 2,5866 & 2,4413 & 1,9165 & 2,0243 & 2,1565 \\
\hline 18 September 2020 & 2,3999 & 2,6941 & 2,5507 & 2,0923 & 2,4249 & 2,5567 \\
\hline 22 September 2020 & 2,8224 & 1,8981 & 1,4900 & 1,3683 & 2,0055 & 2,3440 \\
\hline 23 September 2020 & 3,3652 & 2,6551 & 2,3649 & 2,0698 & 2,7737 & 2,7979 \\
\hline 24 September 2020 & 3,2068 & 2,9135 & 2,7715 & 2,2569 & 2,8107 & 2,8335 \\
\hline 25 September 2020 & 3,5598 & 2,8926 & 2,7874 & 2,2400 & 2,8823 & 3,3005 \\
\hline 29 September 2020 & 3,2361 & 3,0405 & 2,7376 & 2,1948 & 2,8319 & 3,2423 \\
\hline 30 September 2020 & 2,9153 & 2,8270 & 2,6644 & 2,1892 & 2,9342 & 3,1903 \\
\hline Rata-rata & 3,3347 & 2,4852 & 2,3205 & 2,0380 & 2,4253 & 2,6616 \\
\hline
\end{tabular}

Berdasarkan evapotranspirasi tanaman rata-rata pada September 2020, evapotranspirasi terbesar terjadi pada Plectranthus Scutellarioides $(=3,33$ $\mathrm{mm} /$ hari). Sedangkan evapotranspirasi rata-rata terkecil pada September 2020 terukur pada Euodia Ridleyi Dwarf (=2,04 mm/hari). Evapotranspirasi tanaman harian terbesar dan terkecil tersaji dalam Gambar 10.

Evapotranspirasi tanaman harian terbesar terjadi di Plectranthus Scutellarioides, pada 11 September 2020 (= 4,08 mm/hari). Sedangkan evapotranspirasi tanaman harian terkecil terukur di Coleus pada 04 September $2020(=1,21 \mathrm{~mm} / \mathrm{hari})$.

\section{3) Koefisien Tanaman $\left(K_{c}\right)$}

$K_{c} \quad$ dihitung berdasarkan perbandingan evapotranspirasi acuan $\left(E T_{0}\right)$ dan evapotranspirasi tanaman $\left(E T_{c}\right)$. Koefisien tanaman diperoleh dengan membandingkan evapotranspirasi tanaman terhadap evapotranspirasi acuan. Berikut koefisien Plectranthus Scutellarioides pada 01 September 2020:

$$
K_{c}=\frac{3,51 \mathrm{~mm} / \text { hari }}{4,55 \mathrm{~mm} / \text { hari }}=0,77
$$

Hasil perhitungan koefisien tanaman $\left(K_{c}\right)$ untuk tanaman Plectranthus Scutellarioides, Begonia, Coleus, Euodia Ridleyi Dwarf, Euodia Ridleyi, dan Chlorophytum Comosum disajikan dalam Tabel 10. 
Cantilever $\mid$ Volume: 10 Nomor: 01 April 2021 ISSN: 1907-4247 (Print) $\mid$ ISSN: 2477-4863 (Online) $\mid$ Website: http://cantilever.id Arifin Daud, dkk. | Analisis Evapotranspirasi Menggunakan Metode Penman-Monteith pada Vertical Garden

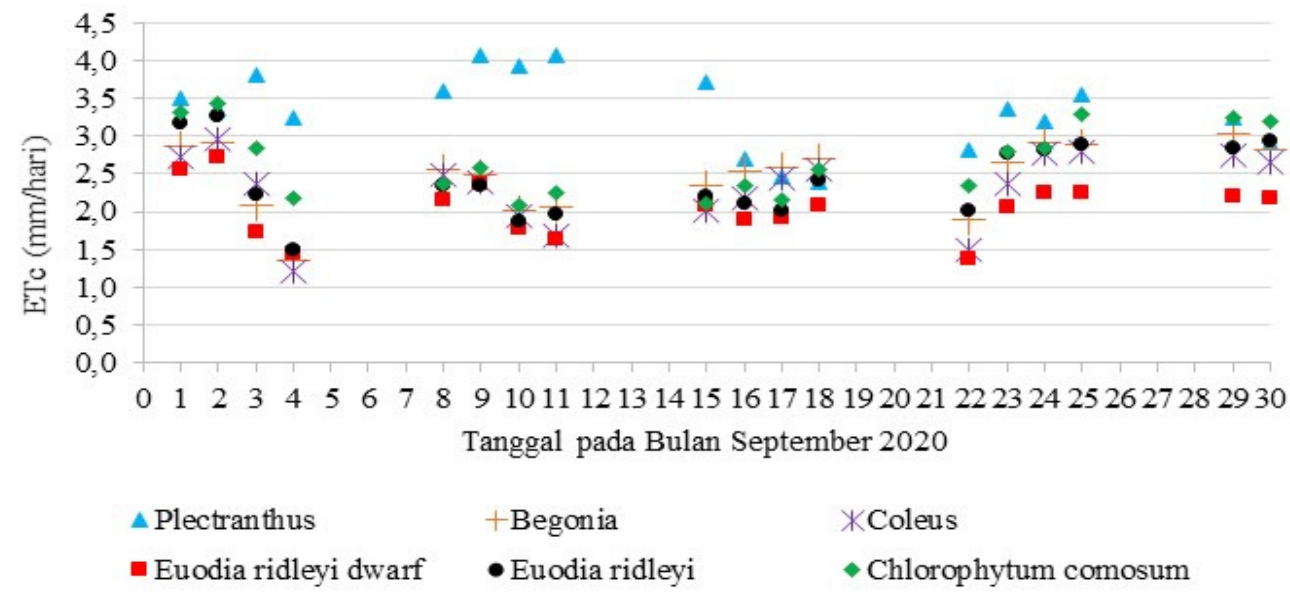

Gambar 10. Grafik nilai evapotranspirasi tanaman

Tabel 10. Nilai koefisien tanaman

\begin{tabular}{ccccccc}
\hline & \multicolumn{5}{c}{ Koefisien tanaman } \\
\cline { 2 - 7 } Tanggal & $\begin{array}{c}\text { Plectranthus } \\
\text { scutellarioides }\end{array}$ & Begonia & Coleus & $\begin{array}{c}\text { Euodia } \\
\text { ridleyi }\end{array}$ & $\begin{array}{c}\text { Euodia } \\
\text { ridleyi }\end{array}$ & $\begin{array}{c}\text { Chlorophy } \\
\text { tum } \\
\text { comosum }\end{array}$ \\
\hline 1 September 2020 & 0,7724 & 0,6304 & 0,6001 & 0,5619 & 0,6951 & 0,7265 \\
2 September 2020 & 1,0459 & 0,9073 & 0,9189 & 0,8491 & 1,0181 & 1,0652 \\
3 September 2020 & 1,2631 & 0,6888 & 0,7876 & 0,5770 & 0,7378 & 0,9462 \\
4 September 2020 & 1,4624 & 0,6072 & 0,5463 & 0,6480 & 0,6688 & 0,9814 \\
8 September 2020 & 0,8980 & 0,6378 & 0,6229 & 0,5362 & 0,5871 & 0,5922 \\
9 September 2020 & 1,0709 & 0,6525 & 0,6300 & 0,6233 & 0,6136 & 0,6773 \\
10 September 2020 & 1,2926 & 0,6642 & 0,6340 & 0,5823 & 0,6163 & 0,6821 \\
11 September 2020 & 1,2600 & 0,6375 & 0,5162 & 0,5033 & 0,6075 & 0,6953 \\
15 September 2020 & 1,5569 & 0,9820 & 0,8466 & 0,8705 & 0,9176 & 0,8845 \\
16 September 2020 & 0,7665 & 0,7200 & 0,6145 & 0,5341 & 0,5939 & 0,6603 \\
17 September 2020 & 0,6215 & 0,6513 & 0,6147 & 0,4825 & 0,5097 & 0,5430 \\
18 September 2020 & 0,6723 & 0,7547 & 0,7145 & 0,5861 & 0,6793 & 0,7162 \\
22 September 2020 & 1,3268 & 0,8923 & 0,7005 & 0,6432 & 0,9428 & 1,1019 \\
23 September 2020 & 0,7737 & 0,6104 & 0,5437 & 0,4759 & 0,6377 & 0,6433 \\
24 September 2020 & 0,7573 & 0,6882 & 0,6545 & 0,5330 & 0,6638 & 0,6692 \\
25 September 2020 & 0,7356 & 0,5977 & 0,5760 & 0,4629 & 0,5956 & 0,6820 \\
29 September 2020 & 0,6695 & 0,6290 & 0,5664 & 0,4541 & 0,5859 & 0,6708 \\
30 September 2020 & 0,5849 & 0,5672 & 0,5345 & 0,4392 & 0,5887 & 0,6401 \\
\hline Rata-rata & 0,9739 & 0,6955 & 0,6457 & 0,5757 & 0,6811 & 0,7543 \\
\hline & & & & & &
\end{tabular}

Berdasarkan koefisien tanaman rata-rata pada September 2020, Plectranthus Scutellarioides memiliki nilai terbesar $(=0,97)$. Sedangkan koefisien tanaman rata-rata terkecil pada Euodia Ridleyi Dwarf $(=0,58)$. Gambar 11 memperlihatkan koefisien tanaman harian terbesar dan terkecil.

Berdasarkan Gambar 11, koefisien tanaman harian terbesar dimiliki Plectranthus Scutellarioides (pada 15 September 2020), yaitu 1,56. Sedangkan koefisien tanaman harian terkecil pada Euodia Ridleyi Dwarf (pada 30 September 2020), yaitu
0,44. Berdasarkan foto dari tiap tanaman, Plectranthus Scutellarioides memiliki daun yang lebih besar. Sedangkan Euodia Ridleyi Dwarf memiliki daun yang lebih kecil. Penempatan Plectranthus Scutellarioides pada bagian paling atas, mempengaruhi koefisien tanaman, yang lebih besar dibanding tanaman lainnya. Morfologi dan penempatan tanaman dapat mempengaruhi koefisien tanaman.

\section{4) Pembahasan}

Evapotranspirasi acuan $\left(E T_{0}\right)$, yang diukur pada sampel di Laboratorium Hidraulika UNSRI menggunakan metode Penman-Monteith, terbesar adalah 4,98 $\mathrm{mm} / \mathrm{hari}$, dan terkecil sebesar 2,13 $\mathrm{mm} /$ hari. Kelembababan, suhu, dan kecepatan angin mempengaruhi evapotranspirasi.

Suhu berpengaruh besar terhadap evapotranspirasi acuan, dibanding kelembapan dan kecepatan angin. Koefisien korelasi suhu terhadap evapotranspirasi acuan $(=0,41)$, lebih besar dibanding koefisien korelasi kelembapan dan kecepatan angin terhadap evapotranspirasi acuan, masing - masing sebesar -0,31 dan 0,29.

Evapotranspirasi (rata-rata) tanaman terbesar adalah evapotranspirasi tanaman Plectranthus scutellarioides $\quad(=\quad 3,33 \quad \mathrm{~mm} / \mathrm{hari})$. Evapotranspirasi tanaman terkecil pada Euodia Ridleyi Dwarf (=2,04 mm/hari). Berdqasarkan evapotranspirasi tanaman yang telah didapat, dapat dilihat bahwa Plectranthus scutellarioides membutuhkan lebih banyak air karena evapotranspirasi tanaman Plectranthus scutellarioides merupakan yang terbesar dibandingkan tanaman lainnya. Jenis, penempatan, dan kondisi (lingkungan) selama pertumbuhan tanaman mempengaruhi evapotranspirasi tanaman. 
Koefisien tanaman (rata-rata) terbesar adalah koefisien Plectranthus Scutellarioides $(=0,97)$. Rata-rata koefisien tanaman terkecil adalah koefisien Euodia Ridleyi Dwarf $(=0,58)$. Evapotranspirasi tanaman berbanding lurus dengan koefisien tanaman.

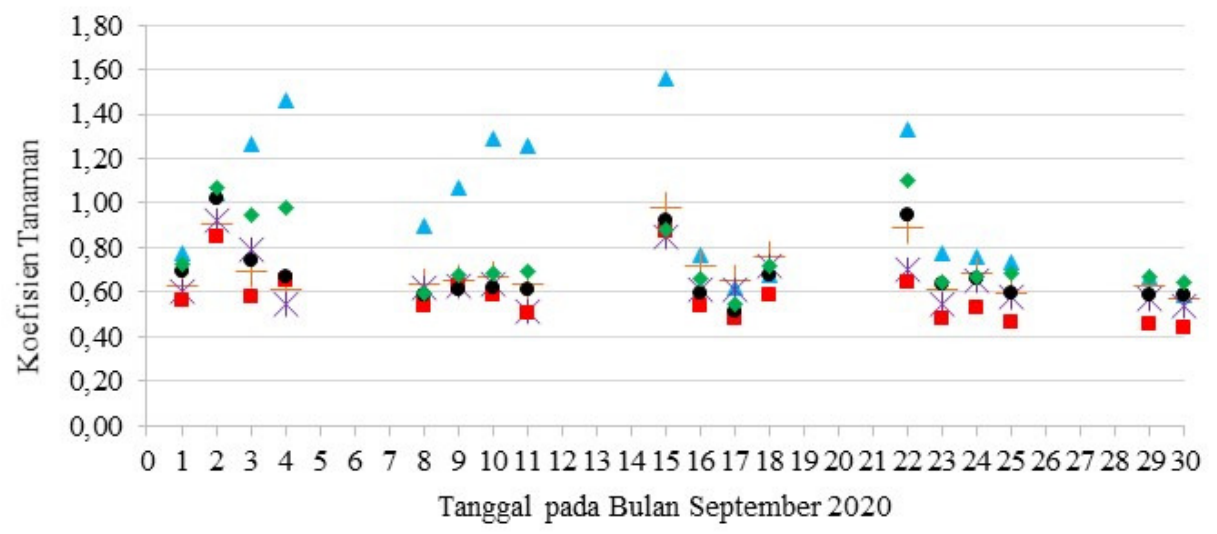

$\Delta$ Plectranthus + Begonia $*$ Coleus $\backsim$ Euodia ridleyi dwarf $\bullet$ Euodia ridleyi $\bullet$ Chlorophytum

Gambar 11. Grafik nilai koefisien tanaman

\section{KESIMPULAN}

Dari penelitian ini, didapat kesimpulan sebagai berikut:

1. Evapotranspirasi acuan $\left(E T_{0}\right)$ terbesar $(=4,98$ $\mathrm{mm} /$ hari $)$, dan terkecil $(=2,13 \mathrm{~mm} /$ hari $)$. Suhu berpengaruh paling besar terhadap evapotranspirasi acuan, selain kelembaban dan kecepatan angin

2. Evapotranspirasi terbesar terukur pada Plectranthus Scutellarioides, yaitu 3,33 mm/hari. Evapotranspirasi tanaman terkecil adalah evapotranspirasi Euodia Ridleyi Dwarf, yaitu $2,04 \mathrm{~mm} /$ hari. Evapotranspirasi tanaman dipengaruhi oleh morfologi tanaman, dimana evapotranspirasi dipengaruhi besarnya daun. Penempatan tanaman juga mempengaruhi evapotranspirasi.

3. Plectranthus Scutellarioides memiliki koefisien terbesar $(=0,97)$. Sedangkan, nilai koefisien tanaman terkecil dimiliki tanaman Euodia Ridleyi Dwarf $(=0,58)$. Semakin besar evapotranspirasi tanaman, maka koefisien tanaman semakin besar.

4. Penelitian dilakukan dalam rentang waktu yang cukup singkat karena dilakukan pada masa pandemic Covid-19, maka penelitian selanjutnya dapat dilakukan dengan rentang waktu lebih lama.

5. Penelitian selanjutnya dapat dilakukan dengan jenis tanaman yang lebih banyak dengan tanaman lokal yang ada.

6. Penelitian selanjutnya dapat dilakukan di lokasi lain dengan kondisi yang hampir sama dengan kondisi di Laboratorium Hidraulika UNSRI.

\section{REFERENSI}

Allen, R. G., Pereira, L. S., Raes D., \& Smith, M. (1998). Crop Evapotranspiration-Guidelines for Computing Crop Water Requirements-FAO Irrigation and Drainage Paper 56. Italia: FAO.

Baruga, C.K., Kim, D., \& Hoi, M. (2019). A National-Scale Drought Assessment in Uganda Based on Evapotranspiration Deficits from Bouchet Hypothesis. Journal of Hydrology 580, 1-44.

Cardozo, D. A. S., Sinobas, L. R., \& Zubelzu, S. (2019). Living Green Walls: Estimation of Water Requirements and Assessment of Irrigation Management. Urban Forestry \& Urban Greening 46, 1-9.

Putranto, D. A. dkk. (2020). Pengukukuran BM Referensi UNSRI dan Penentuan Batas Desa dalam Peningkatan Status Hak Atas Tanah Masyarakat Desa Kembahang 2, Kecamatan Pemulutan, Kabupaten Ogan Ilir. Palembang: Jurusan Teknik Sipil dan Perencanaan Universitas Sriwijaya.

SNI 7745:2012. (2012). Tata Cara Perhitungan Evapotranspirasi Tanaman Acuan dengan Metode Penman-Monteith. Bandung: Badan Standarisasi Nasional.

Virtudes, A. \& Manso, M. ( 2016). Applications of Green Walls in Urban Design. Earth and Environmental Science 44, 16.

Wouw P. M. F., Ros, E. J. M., \& Brouwers, H. J. H. (2017). Precipitation Collection and Evapo(transpi)ration of Living Wall Systems. Building and Environment 126, 221-237.

Zhang, L., Deng, Z., Liang, L., Zhang, Y., Meng, Q., Wang, J., \& Santamouri, M. (2019). Thermal Behaviour of a Vertical Green Façade and its Impact on the Indoor and Outdoor Thermal Environment. Energy \& Buildings, 204. https://doi.org/10.1016/j.enbuild.2019.109502 